\title{
МОВНА РЕПРЕЗЕНТАЦІЯ ОБРАЗУ МІФОЛОГІЧНОГО ГЕРОЯ В БРИТАНСЬКИХ Й УКРАЇНСЬКИХ МЕДІАТЕКСТАХ
}

Робота містить лінгвокультурологічний аналіз способів омовлення міфологічного образу героя в медіатекстах, присвячених процесу Брекзиту й виборів в Украйні. Підтверджено, що медіатексти орієнтовані впливати на аудиторію, а тому активно застосовують міфологічні елементи для посилення такого впливу. Виявлено, що образ героя функиіонує в медіатекстах не відокремлено, а в тісному зв'язку з есхатологічними мотивами, зокрема Апокаліпсису, й образами ворога, битви, війни, спасіння й чуда. Здійснено порівняння характеристик образугероя в британських й украйнських текстах. Виявлено словотвірні гнізда й описано семантичні поля, асоиійовані з відповідними образами.

Ключові слова: культурний герой, міфологічний образ, ворог, медіатекст, битва, есхатологічний мотив.

Krapivnyk H. Textual Representation of the Cultural and Mythological Image of the Hero in British and Ukrainian Mass Media Texts. The study discusses the ways of textual representation of the cultural and mythological image of the hero in mass media texts, selected in British and Ukrainian periodicals and related to Brexit and elections in Ukraine. The work confirmed that media texts are audience-oriented and, therefore, they actively apply mythological elements to intensify their impact. One of the major mythological images is that of the hero who is designed to be a role-model for the masses and their behavior. The consideration of this image verbalization is topical for lingvo-cultural studies as well as for other related fields, e.g. sociolinguistics, social and political studies etc.

The aim of this research was to consider the verbalization of the image of hero in British and Ukrainian media texts. To achieve this aim, it was necessary to fulfil the following tasks: to describe the main properties of media texts; identify the role of the image of the hero among other cultural and mythological images and motifs; specify the notion of the hero and semantically related notions; consider the selected British and Ukrainian mass media texts and analyze the verbalization of the above image therein.

It was shown that the image of the hero functions in the media texts as a semantic element, tightly integrated and overlapping with eschatological motifs, including apocalyptic ones, as well as with the such mythological images as enemy, battle, war, salvation and miracle. The research involved the comparison of hero or heroine descriptions given in British and Ukrainian media texts. Word families and semantic fields, associated with the above images were analyzed. It was also noted that modern 
media texts often involve a combination of communication channels thus becoming multimedial, which was clearly demonstrated in the British textual sources. The prospects for further research were suggested.

Key words: cultural hero, mythological image, enemy, media text, battle, eschatological motif.

\section{Вступ}

Сучасні науковці, констатуючи перенасиченість інформаційного простору, піднімають питання про те, що медійні тексти набувають рис впливовості завдяки особливостям мови, використаної в них (Матисон, 2013: 14). Автори таких медіатекстів створюють певні образи, що є культурно значущими, багатогранними й ефективно привертають увагу аудиторії. Для того, щоб підтримувати постійну зацікавленість реципієнтів текстами масової культури, зокрема медійними, необхідно регулярно піднімати поріг їхньої емоційної чутливості. У результаті цього багато людей втрачає здатність аналізувати отриману інформацію, зокрема через ії надлишковість. Для попередження втоми, байдужості й запобігання їм масова культура активно експлуатує культурно-міфологічні образи, що можуть надихати й бути прикладом або навпаки стимулювати до протидії, якщо змальований образ має чітку негативну конотацію. Одним з таких яскравих образів $є$ культурно-міфологічний герой, що й буде прикладом для мас і їхньої поведінки. Дослідження способів текстової реалізації цього образу є актуальним з позиції лінгвокультурології й інших галузей гуманітарного знання, зокрема для лінгвістики, соціології, політології тощо.

Метою цієї розвідки є аналіз мовної репрезентації образу героя в британських й українських медіатекстах. Для досягнення цієї мети необхідно розв'язати такі завдання: описати основні властивості медіатекстів; визначити місце образу героя серед інших культурноміфологічних образів і мотивів; визначити поняття героя й семантично пов'язаних з ним понять; розглянути обрані тексти британських й українських медіа та проаналізувати мовну реалізацію в них відповідного образу.

Практично будь-який медіатекст $є$ не тільки орієнтованим на аудиторію, але й структурно поліфонічним і містить елементи інтертекстуальності, мультимедійності, а також інтер- і трансмедійності, що надають реципієнтові багатошаровий простір для інтерпретацій, 
доступність подання інформації для сприйняття й розуміння. Різні засоби медіа повсякчас використовують мультимодальність у своїх текстах, що пов'язує їх з іншими аспектами глобального культурного контексту й наявного гіпертексту. Г. Почепцов зазначає, що глобальні структури, на які спираються медійні тексти, містять такі універсальні й завжди актуальні компоненти культури, як смерть, життя, жах тощо (Почепцов, 2001: 41). Важливо зауважити, що медійним текстам з їхньою міфологічністю притаманна формульність і повторюваність певних інваріантних структурних елементів. Теоретичну основу цього питання заклав ще В. Пропп (Пропп, 1928), вивчаючи морфологію казок, а в жанрах художньої літератури Дж. Кавелті (Cawelti, 1976).

Мову засобів масової інформації вивчає медіалінгвістика. Дж. Корнер підкреслює іiі міждисциплінарну природу, що підтверджується різними гуманітарними дослідженнями. Мова мас-медіа залежить від каналу, який ії використовує, і взаємодіє з іншими семіотичними системами (Corner, 1995: 62). М. Яцимірська зазначає, що будь-який медіатекст віддзеркалює мовну особистість автора, його світогляд і світосприйняття, інтелектуальний і когнітивний рівень (Яцимірська, 2007).

Образ ідеального культурно-міфологічного героя (героїні) в медіатекстах представлений надлюдиною, адже міфологічне мислення підказує, що тільки така людина з практично необмеженими можливостями й владою може розв'язати всі проблеми країни (Кириллова, 2006: 138). Цей образ семантично пов'язаний з низкою інших образів і мотивів, які можна об'єднати в одне велике тематичне поле, що асоціюється з есхатологією і, зокрема, Апокаліпсисом. Есхатологічними мотивами $€$ ті, що позначають скінченність, а також повторюваність циклу ініціації, де чергуються процеси руйнації й відродження (Encyclopaedia Britannica). До таких мотивів і образів належать міленарні (у широкому сенсі - міжкультурна концепція очікування періоду повного миру й благополуччя) й месіанські (очікування месії, або спасителя людства, або групи людей). У християнській міфології ідея кінця світу пов’язана з Одкровенням (Апокаліпсисом) Святого Іоана Богослова.

Апокаліптичні мотиви й образи гармонійно входять до досліджуваних текстів, оскільки й міфологічні, і медійні тексти мають на меті викликати певну психоемоційну реакцію адресата для його 
переконання або маніпуляції ним (Яцимірська, 2007: 267-276). Таку ідею переслідують і міфи, що є продуктом колективної свідомості й намагаються вплинути на реципієнта. Медіа самі створюють міфи про катастрофи, з одного боку, провокуючи острах і тривогу, а з другого, надаючи терапевтичний ефект катарсису, де апокаліптичні тексти є інструментами адресантів і адресатів для визначення й експериментування з нинішніми або потенційними ситуаціями.

Природнім агентом фундаментальних змін в есхатологічних медіатекстах $є$ герой або героїня, а також їхні помічники й вороги. На думку Г. Почепцова, «герой є складником пропаганди, яку спрямовано на те, щоб так, як він, діяла кожна людина» (Почепцов, 2019: 379). Він потрібен у мас-медійних текстах, оскільки є орієнтиром для отримувача, який себе ототожнює з героєм, приміряє на себе його роль і експериментує з нею (Фрей, 2005: 72-88). Щодо міфологічного образу ворога, то він $є$ надзвичайно важливим, оскільки активізує опозицію друг-ворог, свій-чужий, толерантність-ксенофобія (див. більше в монографії О. Фельдмана (Фельдман, 2010)). Г. Почепцов вважає, що герой має перемагати для досягнення великої мети. «Чим вище ми піднімаємо героя, тим важливішою стає функція ворога» (Почепцов, 2019: 380). Ворог потрібен задля благополуччя соціосистеми, і він навіть може отримати певну сакральність для своєї підтримки. Під час війни ворога створюють і природнім шляхом, і штучно, віддаючи йому всі наявні в масовій свідомості негативні риси. При тому дуже важливо зважати саме на вербалізацію образу ворога, адже його часто описують красиво, а «роль слів як головного механізму впливу досі недостатньо вивчена» (Почепцов, 2019: 383-385). I. Чернус детально вивчала ситуацію в США й зазначала, що Америці потрібна фігура сильного й могутнього зовнішнього ворога для того, щоб з ним змагатися, боротися, перемогти й вижити (Чернус, 2008).

Утім для більш адекватного лінгвокультурологічного аналізу образу героя доречно надати визначення поняття героя в культурно-міфологічному аспекті. Зокрема, енциклопедія «Мифы народов мира» характеризує героя як «сина або нащадка божества й смертної людини» (Токарев, 2000: 294), що виконує функції захисту й опіки. «Зазвичай герой має неймовірну силу й надлюдські можливості, однак він позбавлений безсмертя» (Токарев, 2000: 295). Енциклопедія також вказує, що «неможливість персонального безсмертя компенсується 
в героїчному світі подвигами й славою (безсмертям) серед нащадків» (Токарев, 2000: 295), при чому в міфах вважають, що герой страждає й безкінечно долає перешкоди та труднощі.

\section{Методи й матеріал дослідження}

Для проведення цього дослідження й досягнення поставленої мети й розв'язання завдань використано такі методи, як метод лінгвокультурологічного й лінгвостилістичного аналізу тексту, порівняльний аналіз і метод суцільної вибірки. У цій розвідці розглянуто британські й українські медіатексти, що містять образ героя й суміжні образи й мотиви, а саме новинні й аналітичні тексти з газети The Guardian i новинного сайту ВBC, (25 статей з кожного джерела за період з березня до червня 2019 року й кінця серпня-вересня 2019 року - період активного процесу Брекзиту), а також відповідна кількість новинних і аналітичних статей з Українського Тижня й вебсайту української служби ВВС (з лютого по квітень 2019 року - період президентської кампанії).

\section{Результати та дискусії}

У досліджуваний період обидві країни зіткнулися із серйозними суспільно-політичними викликами (у Сполученому Королівстві - питання Брекзиту, в Україні - президентські вибори), що миттєво призвели до медійного галасу, або хайпу. Як було зазначено, мова медіа $€$ надзвичайно впливовим інструментом і зброєю. Спосіб називання, брендування є значущим, оскільки слова виступають символами, що спрощують комунікацію й визначають сприйняття й світорозуміння (Барден, 2012: 125). Саме тому важливо визначити мовні засоби, які використовують для створення образів, зокрема героя / антигероя (порівняймо «betrayal» у британських або «зрада або перемога» в українських медіатекстах).

Ідеологічно й віртуально створений образ Брекзиту не міг обійтися без лідера - людини або групи людей, які могли виконати завдання (deliver Brexit/get the Brexit done), навіть якщо воно здавалося непосильним. Численні тексти демонструють сам соціально-економічний і політичний процес як такий, що матиме негативні наслідки, принесе труднощі й непорозуміння. Місією героя Брекзиту є вихід з ЄС зі збереженням вигідних для своєї країни міжнародних відносин, зокрема із сусідами з континентальної Європи. Суперечки й непорозуміння 
всередині консервативної партії в розпал 2019 року текстуально прокоментовано так: "How Brexit is causing the strange death of British conservatism» (Freedland, 2019). При цьому героїнею Брекзиту спочатку мала стати, але не стала Тереза Мей, яка так і не змогла «deliver Brexit». Незважаючи на всі намагання Прем'єрки втілити в життя рішення референдуму, їй цього не вдалося. В одному з досліджуваних текстів провідний журналіст газети The Guardian Г. Юнге емоційно висловлюється й створює гіперболізовану картину поточної ситуації в Британіiі: "May put it two years ago, to become "a great, global trading nation that is respected around the world and strong, confident and united at home". Instead we look like a cross between a beggar and basket case» (Younge, 2019). Крім того, аналізовані тексти цитують слова представника іiі уряду й констатують, що пані Мей довелося працювати зі складними питаннями, що не знаходили розв'язання зацікавленими сторонами. Зокрема, Дж. Хант зазначив: «No prime minister in living memory has been tested in the way that she has. She has never once wavered in her strong belief that the Conservative party's mission is to deliver the Brexit that people voted for» (Мейсон, 2019). Автор цієї статті додає, що Дж. Хант заявив про завдання депутатів досягти консенсусу й запобігти “паралічу" через Брекзит.

Наступником Мей як героїні виходу з ЄС став Б. Джонсон, ставлення до якого є доволі неоднозначним. Це демонструють і тексти статей The Guardian, і комікси-карикатури Кріса Ріддела (Chris Riddell), що їх регулярно розміщують у цьому виданні. Ці тексти $€$ мультимедійними, синтетичними, що, як було вказано, $є$ типовим для медіатекстів. У цьому разі аудиторія одночасно отримує синтез друкованих і графічних новин, тоді як поряд розміщено також фото, відео- й аудіоматеріали. Усі комікси К. Ріддела містять зображення героя / героїв і їхніх опонентів, сповнені апокаліптики, що виражено прямо або опосередковано, графічно й вербально (Riddell, 2019). Так автор із сатиричної позиції ставить акценти на недоліках і проблемних питаннях суспільства, що потребують негайного розв'язання.

Друковані українські передвиборчі слогани на президентських перегонах не містили подібної сатири, що, можливо, пов'язано з екстралінгвальним фактором - воєнним конфліктом. Для України культурним міфологічним героєм медійних текстів того часу став майбутній президент держави В. Зеленський. Його головним суперником 
виступив, звичайно, тоді чинний президент України П. Порошенко. Змагання за владу й роль героя країни, що воює й намагається стати успішною й передовою на міжнародній арені, містило активну медійну полеміку, вербальні перепалки, конфлікти й протистояння. При цьому акцентувалися певні аспекти, що можна назвати крайніми й не поміркованими. Медіатексти працювали на поляризацію думок і позицій, а не на їх зближення. У численних текстах образи героя і його опонента омовлювалися, зокрема, за допомогою лексичних одиниць, що створили ціле семантичне поле.

Усього було виявлено 24 елементи цього поля, що стосуються В. Зеленського: Камікад-Зе, Зе Корпоратив, Зе команда, зеленіти, Зеля, казус Зеленського, Зе-Загроза, Зе, Зе!Президент, Зе!Life, Зе-икола, УкраїнаЗе, Зеленський - іграшка, Голобородько, маріонетка, ширма, лідер «приколістів», Слуга народу, агент, проект, гіперпопулістський проект Зе, віртуальний, голограма, український Макрон. Словотвірне гніздо, що базується на прізвищі цього кандидата, було здебільшого сформовано шляхом скорочення, словоскладання й телескопії (13 одиниць). Як неологізми, пов'язані із тоді чинним Президентом П. Порошенком, зафіксовано 5 одиниць: Порох, порохобот, ПП, кондитер, Банкова.

Культурно-міфологічний образ героя можна трактувати як біблійний, оскільки апокаліптичні тексти розповідають про Спасителя (Saviour), що має виконати свою місію й створити чудо для людей. В аналізованих текстах таким чудом $€$ успішний вихід Британії з $Є С$ (або рішення залишитися) й успішне подолання військового конфлікту та вихід з економічної кризи в Україні.

Так само семантичне поле сформувалося й навколо Брекзиту і його героїв. На сайті компанії ВВС було навіть організовано довідник з Брекзиту («Brexit: Jargon-busting guide to the key terms» (Brexit: Jargonbusting guide, 2019)) й інші мультимедійльні тексти, що пояснюють відповідну термінологію, надають аналітику й підвищують рівень обізнаності в суспільстві. Лексичними одиницями на позначення виходу Британії й суміжних явищ у проаналізованих медіатекстах $є$ Brexit, exit, Brexodus, Exodus, divorce (bill), referendum, ex-Brexit, post-Brexit, pro-European, pro-EU, pro-Brexit, Brexiter (Brexiteer), pro-remain, Leavers, Remainers, Remoaners, divergence й out-and-out remain position. У проаналізованих текстах було виявлено 14 лексем, що мають нейтральне 
або позитивне семантичне забарвлення, наприклад, soft Brexit, Brexit campaigner, Brexit policy, Brexit spectrum, managed Brexit, negotiated Brexit, Brexit solution тощо. Водночас негативну конотацію мала більша кількість лексичних одиниць, а саме 49, що їх можна поділити за тематикою на такі групи: тупик («Brexit deadlock», «Brexit impasse», «Brexit extinction»); чаc («moment of truth», «Brexit extension», «Brexit day», «transition period»); нестабільність («vortex of Brexit», "disorderly Brexit», "uncertainty over Brexit», "avoid a paralysis over Brexit»); криза ( «hard Brexit», "no-deal departure», no-deal disaster, «Brexit has precipitated this crisis», "Brexit has broken us», Brexit nightmare); люди (Casualty of Brexit, $\mathrm{Mr}$ No-Deal, Brexit extremists, «Brexit-weary voters»).

Слід зазначити, що в британських текстах образ ворога можна знайти, наприклад, у такому контексті: «...foreign secretary Jeremy Hunt likened the EU to the Soviet Union and whose current prime minister compared it to the Nazis» (Luyendijk, 2019). На думку автора, більша частина еліти й простих виборців швидше нетолерантні один до одного, і навпаки, коли мова заходить про членство в ЄС, вони себе отруюють «with lies, delusions and the demonisation of everyone with a different opinion» (Luyendijk, 2019). При цьому ЄС не може виступити в ролі Спасителя для Британії, оскільки остання «does not want to save itself» (Luyendijk, 2019). Ворогів описують, використовуючи перебільшення й прецедентні тексти, як, наприклад, у заголовку доволі старої статті газети Daily Mail (04 листопада 2016 р.): «...The Enemies of the People», що їі цитує газета The Guardian. У цьому разі текст заголовка $€$ прецедентним - фразеологізмом, що його широко використовують протягом століть (від лат. hostis publicus), зокрема ще В. Шекспір у своїй трагедії «Коріолан» («Coriolanus»), Х. Ібсен назвав одну зі своїх п’єс «Ворог народу» («An Enemy of the People»), а пізніше цей фразеологізм був популярним за радянських часів і навіть зараз у риториці Д. Трампа. Іншим способом опису ворога є стилістичний прийом літоти, що, навпаки, свідомо применшує значущість ворога (dastardly foreigner) (Balls, 2019). Ворога часом називають у текстах зрадником (traitor). У британському контексті так називали членів Парламенту, що не погодилися на угоду про вихід, запропоновану Терезою Мей, тоді як спікер захистив своїх колег «Speaker says no MP is 'traitor' amid suggestions PM is pitting the public against them» (Younge, 2019). Подібно слово treason й інші семантично близькі лексеми, стилістично 
марковані й експресивні, використовують для «pepper and pollute the language of rightwing politicians and commentators» (Henley, 2019) I "Terms such as "betrayal", "surrender", "plots by traitors" "traitors to the national interest" and "enemies of the people" are on the front pages routinely» (Luyendijk, 2019). У проаналізованих медіатекстах Б. Джонсона називають liar, порівнюють його 3 mad general i «the father of lies» (Henley, 2019). Проте його політичного суперника, лідера лейбористів Дж. Корбіна описують як нерішучу людину, адже зустріч його партії виявилася доволі апокаліптичною: «The party conference was plunged into Brexit disarray and then into downright chaos» (Henley, 2019).

Британський референдум щодо виходу з Євросоюзу був певною мірою попередженням і запобіжником. Його результат був обумовлений острахом навали мігрантів, що асоціюється з біблійними словами з останньої вирішальної апокаліптичної битви й зовнішньої навали: «А через тисячу років звільнено буде сатану з в'язниці. Тоді піде він по всьому світу обманювати народи, які звуться Го і і Маsоs, й обдурить їх і зведе для війни. І збереться там стільки людей, щьо і не перелічити їх, як піску на березі моря. Вони наступатимуть по всій землі, й оточать стан людей Божих і Його улюблене місто, але вогонь зійде з Небес і пожере їх» (Євангеліє від Іоана 20:7-9)).

Попередження й вимоги щодо вживання заходів запобігання часто містилися в українських аналізованих текстах, наприклад: «Парламент. Виставити запобіжники» (Малко, 2019b); “Дуже скоро день, коли він погодився стати кандидатом в президенти, видаватиметься йому найжахливішим у житті, а мрія прокинутися, щоб його безконечний кочмарний сон нарешті закінчився, переросте в параною» (Малко, 2019a).

Однак суспільний хаос і безлад в очікуванні зазначених подій і підготовці до них співіснує з міфологічним мотивом відродження (відтворення» "...pangs of optimism, and a renewed sense <...> an embryonic leftwing politics that might at last speak to a future..." (Harris, 2019). Журналіст вважає, що на зміну сьогоднішній темряві й суму прийдуть нові думки: «Brexit has blown the lid off conventional notions of political possibility, allowing the left's grassroots to start offering grounds for optimism. In the midst of all-enveloping darkness, that might provide just enough flickering light to keep us going» [ibid.]. 
Ідея надії на відновлення вербалізована й у проаналізованих українських медіатекстах. Думка експерта, викладена в Тижні, указує на те, що фундаментальні зміни в керівництві країни можуть «дати вікно можливостей для перезавантаження російсько-украйнських відносин» (Вовчук, 2019а). Інший журналіст Тижня визнає, що «попри певну конфронтацію поглядів жителів Донбасу та інших украйнських регіонів, одностайною є думка про важливість встановлення миру та повернення окупованих територій» (Рябоштан, 2019).

У цьому аспекті доцільно звернутися до структури есхатологічного міфу, де світ спочатку поринає в хаос, люди втрачають будь-які святі речі й місця, праведники страждають від репресій, ресентимент розквітає, влада не забезпечує справедливість, моральний дух падає тощо. Те, що колись вважалося поза нормою, у такий період є звичним, людство розділяється на дві нерівноправні частини - праведники й негідники (вороги). Процеси, що відбувалися в Великій Британії в досліджуваний період, мають схожий характер. Зокрема, у зробленому ВВС огляді газет (ВВС Papers Review, 12.06.2019) вказано, що видання Financial Times заявляє: «Labour will draw 'battle lines' by leading a cross-party move to prevent the UK leaving the EU without a deal». Ця газета також надає думку експерта про те, що тривала відсутність перемовин між ЄС і Британією може мати руйнівний ефект («devastating impact») для британської економіки.

Битва за Брекзит (battle for Brexit) точилася у форматі перемовин і перепалок щодо того, як і на яких умовах буде відбуватися процес виходу. Крім того, ця битва й рішення набували екзистенційності, адже потребували відповідальності й свідомого ставлення всіх сторін до свого вибору (BВC Papers Review, 12.06.2019). Указаний образ битви можна впевнено розглядати як ключовий у міжкультурній міфологічній есхатологічній системі. Цю подію можна визначити, як вирішальну битву між праведниками й богами з одного боку, і демонами, темними силами й людьми, що їх підтримують, з другого. У результаті цієї битви світ переживає руйнацію, а потім відроджується для того, щоб стати кращим й оновитися. Поняття битви $є$ багатогранним з моральної, фізичної, економічної, юридичної й інших позицій. Наприклад, провідний аналітик ВВС News П. Барнз (Р. Barnes) вважає, що "If there is no new deal... there is likely to be a legal battle» (Barnes, 2019). Однак битви можна уникнути юридично, якщо, як додає автор, 
відмінити Брекзит («cancelling Brexit») [ibid.]. Різні аспекти битв можна знайти й в аналізованих українських текстах. Зокрема, після першого туру президентських виборів «розгорілася справжня битва» / «Кожен пост у стилі ми - воїни світла, а вони - насєлєніє - це чергова иеглинка у монумент перемоги Зе» (Страх і ненависть у Фейсбуку, ВВС, 2 квітня 2019).

Образ війни частково семантично накладається на образи катастрофічної події, руйнації, страху й, звичайно, героя. Оскільки ці образи користуються популярністю серед реципієнтів і викликають цікавість, їх широко використовують для мовної гри й створення яскравого образу - «картини» (часто 3 гіперболізацією). Це можна підтвердити текстом статті в The Guardian, де журналіст описує риторику війни й дії Прем'єр-міністра. До прикладу він зазначає, що «Boris Johnson wants war. He knows Britons love war, especially with Europe. He and his allies have turned a technical debate about trade policy into a Battle of Britain. They suggest ludicrously that the national economy faces an existential threat from Europe. They forget that in times of war countries seek to cohere, not descend into partisan strife» (Jenkins, 2019). У цій статті С. Дженкінс продовжує критикувати діяльність Прем'єра як героя Брекзиту: «... job as prime minister should be to get a deal on Brexit and not stall one...». У міфологічного героя зазвичай $€$ помічник(и) або асистент(и). Цей елемент також віддзеркалено в проаналізованих текстах, наприклад: «... minister for no deal, Michael Gove... was like an air raid warden from Dad's Army». На думку автора статті, "Johnson ... comes across as a mad general. In the Commons he was shrieking abuse at Jeremy Corbyn and accusing him of "defeat ... shameful surrender ... white flag ... chlorinated chicken ... shit or bust» (Jenkins, 2019). Фактично образ героя Прем'єра представлено як антигероя, зокрема через неприємну ситуацію з риторикою, що їі використав пан Джонсон «Johnson's hapless chancellor, Sajid Javid, was left squirming in obfuscation on the BBC yesterday morning» (ibid.).

В українських текстах образ війни має й реалістичний, і риторичний аспекти. Останній більше стосується цієї роботи, оскільки він стилістично забарвлений і експресивний. Досліджувані медіатексти містять численні контексти з вербалізацією цього образу. Наприклад, «Епіфаній назвав Російську правоставну иеркву останнім форпостом президента РФ Володимира Путіна в Украӥні» (Епіфаній назвав РПЦ, 
02 лютого 2019) / «спроби мобілізувати патріотичних вибориів, використовуючи загрозу російської агресії, може переконати підтримати його» (Вовчук, 2019а) / «напередодні виборів на армію і суспільство спрямований 'обстріл з гармат інформаційної війни'» (Порошенко повідомив, що ТСК..., 11 березня 2019).

Суспільні процеси в обох державах певною мірою схожі. В українській президентській кампанії слоган «Армія. Мова. Віра.» був задекларований чинним Президентом, тоді як британський рух з («appetite for nationalism») отримав поштовх до бурхливого розвитку завдяки референдуму («unleashed by the referendum» (Henley, 2019). Утрата довіри людей до Петра Порошенка знайшла таке текстове відображення: «Його (Порошенка - Г.К.) очевидної нездатності виконати надії своїх виборців 2014 року / особистий... публічний патріотизм не перетворюється на прощення його економічних недоліків та бізнес-угод» (Вовчук, 2019а). Навпаки, основний конкурент чинному Президенту України мав суспільну довіру: «Головний актив Зеленського - його бездоганна репутація» (Вовчук, 2019а).

Щодо цього Б. Джонсон зазначив, що він був готовий до «titanic clash with Brussels». У разі ж будь-якої затримки з процесом виходу він попереджав про вірогідну поразку й країни, і його партії «(any) delay means defeat... and Corbyn» (BBC Papers Review, cit. from Daily Express dated 12.06.2019). Отже, у міфологічному розумінні Б. Джонсон позиціонує себе як героя, що має сили здійснити подорож, подолати всі труднощі й знайти так званий Святий Грааль. Так його народ отримає спасіння, тоді як за невпевненістю, а саме paralysing uncertainty очікування Брекзиту, прийде сприятливий період пост-Брекзиту. За три місяці, до вересня 2019 року, бойова ситуація з переговорами («battlefield» landscape) змінилася, як пише BBC: «Mr Johnson is a prime minister deadlocked in Westminster and deadlocked in Brussels» (Parliament suspension: Angry Commons. ВВС, 2019). Тексти The Guardian чітко показують суперечливе ставлення до Б. Джонсона й Дж. Корбіна: «The Tory party has elected the most callous, ruthless, mendacious and superficial politician in living memory as its leader and thereby prime minister./... the Labour party is led by someone who campaigned for the leadership on the promise of straight talking, then obfuscated about Brexit from the moment he got the job» (Luyendijk, 2019). 
Міфологічний герой втілює сотеріологічну ідею спасіння. Його допомога часом пов'язана із самопожертвою, і він до неї готовий. Так міфологічний образ чуда переплітається з образами героя й спасіння. Мова йде про необхідність подолання й виживання, застосування героєм надзвичайних рис. При цьому реципієнтам медіатекстів, що містять такі образи й історії, зазвичай не потрібні вагомі докази, оскільки емоційний складник є більш значущим і саме «чудо показує тріумб життя» (Аронсон, 2007: 30).

В українському медійному ландшафті ця риса героя отримала дещо сатиричний, часом навіть гіркий відтінок. На думку експертки Atlantic Council Мелінди Харінг, що іiі наводить видання, «Зеленський - ідеальний кандидат: він грає на телебаченні президента, який відсікає руку корумпованого депутата... Зеленський пообіияв, що ніхто не отримає особливого ставлення, усунути депутатський імунітет і підтримати антикорупиійні інституиї Украйни... Однак у нього немає політичного досвіду» (Вовчук, 2019в). В іншому аналізованому тексті автор пише: «Припустімо, що Зе раптом виконає обіиянку $i$ справді <...> спробує залучити до роботи людейпрофесіоналів. <..> Дива іноді трапляються, й ие було б ідеально. Втім, у таких історіях завжди є численні «але». <...> Можна навіть помріяти, що Зеленський раптом відчує себе сильним політиком, <..> однак иее фантастика. Немає жодних підстав изим марити» (Малко, 2019а).

\section{Висновки}

Отже, дослідження британських і українських медіатекстів показало, що культурно-міфологічний образ героя є важливим компонентом їхнього семантичного наповнення. Цей образ не є відокремленим, а входить до великого поля есхатологічних мотивів і образів, де тісно перекликається з мотивом Апокаліпсису, образами ворога, битви, війни, спасіння й чуда. Лінгвокультурологічний аналіз текстів дав змогу виявити засоби мовної реалізації зазначеного образу, а в британській пресі й мультимедійні. Оскільки медіатексти дуже чітко віддзеркалюють те, як сучасна мова реагує на поточні суспільно-політичні процеси, то було б доречно продовжити їхній аналіз з огляду на стрімкі зміни, що відбуваються у країнах. 


\section{ЛІТЕРАТУРА}

1. Аронсон О. Коммуникативный образ. Кино. Литература. Философия. Москва: Новое литературное обозрение, 2007. 384 с. 2. Барден Н., Уильямс Т. Слова и символы. Язык и коммуникация в терапии. Харьков: Гуманитарный центр, 2012. 180 с. 3. Вовчук X. Світові ЗМІ про вибори президента України: шанси головних кандидатів і майбутні відносини з РФ. Тиждень. URL: https://tyzhden.ua/World/226279. 4. Вовчук X. Світ про результати першого туру виборів президента України: нове політичне обличчя та стійкий лідер. Тиждень. URL: https://tyzhden.ua/World/228653. 5. Епіфаній назвав РПЦ останнім форпостом Путіна в Україні. Тиждень. URL: https:// tyzhden.ua/News/226140. 6. Євангеліє від Іоана. URL: http://hram.in.ua/biblioteka/ bibliia/166-book166/2173-title2609. 7. Кириллова Н. Б. Медиакультура: от модерна к постмодерну. 2-е изд. Москва: Академический Проект, 2006. 448 с. 8. Малко Р. Камікад-Зе. Тиждень. URL: https://tyzhden.ua/Politics/228722. 9. Малко Р. Парламент. Виставити запобіжники. Тиждень. URL: https://tyzhden.ua/Politics/228993. 10. Матисон Д. Медиа-дискурс. Анализ медиа-текстов. Исследования медиа и культуры. Харьков: Гуманитарный центр. 2013. 264 с. 11. Мифы народов мира: в 2 т. / под ред. С. А. Токарева. Москва: Большая Российская Энциклопедия, 2000. Т. 1. 671 с. 12. Порошенко повідомив, що ТСК назве причетних до корупції в оборонній сфері. Тиждень. URL: https://tyzhden.ua/News/227617. 13. Почепцов Г. Г. Теория коммуникации. Москва: Рефл-бук, 2001. 656 с. 14. Почепцов Г. Г. Виртуальные войны. Фейки. Харьков: Фолио. 2019. 507 с. 15. Пропп В. Морфология сказки. Ленинград: Academia. 1928. 153 с. 16. Рябоштан I. Повернення Донбасу очима українців. URL: https:/tyzhden.ua/ Society/226765. 17. Страх і ненависть у Фейсбуку: як українці сваряться через вибори. BBC. URL: https://www.bbc.com/ukrainian/features-47784858. 18. Фельдман О. Б. Від ксенофобії до ксенології: філософсько-антропологічний аналіз. Харків: В. В. Кудлай, 2010. 192 с. 19. Фрэй Дж. Н. Как написать гениальный детектив. Санкт-Петербург: Амфора. 2005. 316 с. 20. Яцимірська М., Драган Н. Медіатекст як продукт журналістської творчості (психолінгвістичний аналіз логічного сприйняття та емоцій). Lviv: Вісн. Львівського ун-ту, 2007. Вип. 30. С. 267-276. 21. Balls К. (2019). Boris Johnson may not get an election. But he can still avoid asking for a Brexit delay. The Guardian. URL: https://www.theguardian.com/commentisfree/2019/sep/06/prime-minister-warrhetoric-trade-negotiations. 22. Barnes P. (2019). Brexit: What happens now? BBC News. URL: https://www.bbc.com/news/uk-politics-46393399. 23. Brexit: Jargon-busting guide to the key terms. (2019). BBC News. URL: https://www.bbc.com/news/uk-43470987. 24. Cawelti J. G. (1976). Adventure, Mystery, and Romance. Formula Stories as Art and Popular Culture. Chicago: University of Chicago Press. P. 142-154. 25. Chernus I. (2008). Apocalypse Management. Eisenhower and the Discourse of National Insecurity. Stanford. 26. Corner J. (1995). Documentary television: the scope for media linguistics. AILA Review. Applied Linguistics Across Disciplines, 12, 62-67. 27. Eschatology. Encyclopaedia Britannica. URL: https://www.britannica.com/topic/eschatology. 28. Freedland J. (2019). How Brexit is causing the strange death of British conservatism. The Guardian. URL: https://www. theguardian.com/commentisfree/2019/jun/07/brexit-strange-death-british-conservatism. 29. Harris J. (2019). Brexit may feel apocalyptic - but radical new ideas are taking root. The Guardian. URL: https://www.theguardian.com/commentisfree/2019/sep/30/brexitapocalyptic-radical-new-ideas-progressive-thinking. 30. Henley J. (2019). Brexit weekly 
briefing: no evidence of progress on deal - despite claims. The Guardian. URL: https:// www.theguardian.com/politics/2019/sep/24/brexit-weekly-briefing-no-evidence-ofprogress-on-deal-despite-claims?utm_term=RWRpdG9yaWFsX0JyZXhpdEJyaWVmaW5 nLTE5MDkyNA\%3D\%3D\&utm_source=esp\&utm_medium $=$ Email\&utm_campaign $=\mathrm{Br}$ exitBriefing\&CMP=brexitbriefing_email. 31. Jenkins S. The prime minister revels in war rhetoric, but could end up its victim. The Guardian. 2019. URL: https://www.theguardian. com/commentisfree/2019/sep/06/prime-minister-war-rhetoric-trade-negotiations. 32. Luyendijk J. (2019). Europe isn't the enemy - demonising us is undermining Britain. The Guardian. URL: https://www.theguardian.com/commentisfree/2019/sep/29/europeisnt-enemy-undermining-britain-tories-nasty-party. 33. Mason R., Weaver M. (2019). Bercow defends MPs after May blames them for Brexit delay. The Guardian. URL: https:// www.theguardian.com/politics/2019/mar/21/theresa-may-tone-brexit-speech-frustrationjeremy-hunt. 34. Parliament suspension: Angry Commons exchanges as MPs return to work. (25 September 2019). BBC News. URL: https://www.bbc.com/news/uk-politics-49826524. 35. Riddell Ch. (2019). No-deal Brexit: the fourth horseman of the Apocalypse - cartoon. The Guardian. URL: https://www.theguardian.com/commentisfree/picture/2019/aug/24/ no-deal-brexit-the-fourth-horseman-of-the-apocalypse-cartoon\#img-22. 36. Younge G. (2019). Brexit is not the cause of Britain's political breakdown a symptom. The Guardian. URL: https://www.theguardian.com/commentisfree/2019/mar/21/brexit-political-crisisbritain.

\section{REFERENCES}

1. Aronson, O. (2007). Kommunikativnyi obraz. Kino. Literatura. Filosofiya. [Communicative image. Cinema. Literature. Philosophy.]. Moscow: Novoye literaturnoye obozreniye - New Literary Review [in Russian]. 2. Balls, K. (2019). Boris Johnson may not get an election. But he can still avoid asking for a Brexit delay. The Guardian. Retrieved from https://www.theguardian.com/commentisfree/2019/sep/06/prime-minister-war-rhetoric-trade-negotiations [in English]. 3. Barden, N., Williams, T. (2012). Slova i simvoly. Yazyk $i$ kommunikatsiya $v$ terapii [Words and Symbols. The Language of Communication in Therapy]. Kharkiv: Humanitarian Center [in Russian]. 4. Barnes, P. (2019). Brexit: What happens now? BBC News. Retrieved from https://www.bbc.com/news/uk-politics-46393399 [in English]. 5. Brexit: Jargon-busting guide to the key terms. (2019). BBC News. Retrieved from https://www.bbc.com/news/uk-43470987 [in English]. 6. Cawelti, J. G. (1976). Adventure, Mystery, and Romance. Formula Stories as Art and Popular Culture, (pp. 142-154). Chicago: University of Chicago Press [in English]. 7. Chernus, I. (2008). Apocalypse Management. Eisenhower and the Discourse of National Insecurity. Stanford [in English]. 8. Corner, J. (1995). Documentary television: the scope for media linguistics. AILA Review. Applied Linguistics Across Disciplines, 12, 62-67 [in English]. 9. Eschatology. Encyclopaedia Britannica. Retrieved from https://www.britannica.com/topic/eschatology [in English]. 10. Epifanii nazvav RPC ostannim forpostom Putina v Ukraiini [Epifanii called RPC Putin's last outpost in Ukraine]. (2019). Tyzhden - Week. Retrieved from https://tyzhden.ua/News/226140 [in Ukrainian]. 11. Evangeliye vid Ioana [Gospel according to St. John]. Retrieved from http://hram.in.ua/biblioteka/bibliia/166-book166/2173-title2609 [in Ukrainian]. 12. Feldman, A. B. (2010). Ot ksenofobii k ksenologii: filosofsko-antropologicheskii analiz. [From xenophobia to xenology: philosophical-anthropological analysis]. Kharkiv: H. S. Skovoroda 
Kharkiv National Pedagogical University [in Russian]. 13. Freedland, J. (2019). How Brexit is causing the strange death of British conservatism. The Guardian. Retrieved from https:// www.theguardian.com/commentisfree/2019/jun/07/brexit-strange-death-british-conservatism [in English]. 14. Frey, J. N. (2005). Kak napisat' genial'ny detektiv. [How to Write a Damn Good Mystery]. (Vul' N. trans.). Saint-Petersburg: Amfora [in Russian]. 15. Harris, J. (2019). Brexit may feel apocalyptic - but radical new ideas are taking root. The Guardian. Retrieved from https://www.theguardian.com/commentisfree/2019/sep/30/brexit-apocalyptic-radical-new-ideas-progressive-thinking [in English]. 16. Henley, J. (2019). Brexit weekly briefing: no evidence of progress on deal - despite claims. The Guardian. Retrieved from https://www.theguardian.com/politics/2019/sep/24/brexit-weekly-briefing-no-evidence-of-progress-on-deal-despite-claims?utm_term=RWRpdG9yaWFsX0JyZXhpdEJyaWVmaW5nLTE5MDkyNA\%3D\%3D\&utm_source=esp\&utm_medium=Email\&utm_ campaign=BrexitBriefing\&CMP=brexitbriefing_email [in English]. 17. Jenkins, S. (2019). The prime minister revels in war rhetoric, but could end up its victim. The Guardian. Retrieved from https://www.theguardian.com/commentisfree/2019/sep/06/prime-minister-war-rhetoric-trade-negotiations [in English]. 18. Kirillova, N. B. (2006). Mediakultura: ot moderna $k$ postmodernu. [Mediaculture: from modernity to postmodernity]. Moscow: Academic Project [in Russian]. 19. Luyendijk, J. (2019). Europe isn't the enemy - demonising us is undermining Britain. The Guardian. Retrieved from https://www.theguardian.com/ commentisfree/2019/sep/29/europe-isnt-enemy-undermining-britain-tories-nasty-party [in English]. 20. Malko, R. (2019a). Kamikad-Ze [Kamikaze]. Tyzhden - Week. Retrieved from https://tyzhden.ua/Politics/228722 [in Ukrainian]. 21. Malko, R. (2019в). Parlament. Vystavyty zapobizhnyky [Parliament. Safeguards required]. Tyzhden - Week. Retrieved from https://tyzhden.ua/Politics/228993 [in Ukrainian]. 22. Mason, R., Weaver, M. (2019). Bercow defends MPs after May blames them for Brexit delay. The Guardian. Retrieved from https://www.theguardian.com/politics/2019/mar/21/theresa-may-tone-brexit-speech-frustration-jeremy-hunt [in English]. 23. Matheson, D. (2013). Media-diskurs. Analiz media-tekstov. Issledovaniya media $i$ kul'tury [Media discourses: Analysing media texts. The study of media and culture]. Kharkiv: Humanitarian Center [in Russian]. 24. Parliament suspension: Angry Commons exchanges as MPs return to work. (25 September 2019). $B B C$ News. Retrieved from https://www.bbc.com/news/uk-politics-49826524 [in English]. 25. Pocheptsov, H. H. (2001). Teoryya kommunykatsyy [Theory of Communication]. Moskva: Refl-book [in Russian]. 26. Pocheptsov, H. H. (2019). Virtualnye voiny. Feiki [Virtual Wars. Fakes.]. Kharkiv: Folio [in Russian]. 27. Poroshenko povidomyv, shcho TSK nazve prychetnykh do koruptsii v oboronnii sferi [Poroshenko informed that TSK would name those involved in corruptive activities]. (11 березня 2019). Tyzhden - Week. Retrieved from https://tyzhden.ua/News/227617 [in Ukrainian]. 28. Propp, V. (1928). Morfologia skazki. [Morphology of Fairy Tales]. Leningrad: Academia [in Russian]. 29. Riddell, Ch. (2019). No-deal Brexit: the fourth horseman of the Apocalypse - cartoon. The Guardian. Retrieved from https://www.theguardian.com/commentisfree/picture/2019/aug/24/no-deal-brexitthe-fourth-horseman-of-the-apocalypse-cartoon\#img-22 [in English]. 30. Ryaboshtan, I. (2019). Povernennya Donbasu ochyma ukrayintsiv [The Return of Donbas seen by Ukrainians]. Retrieved from https://tyzhden.ua/Society/226765 [in Ukrainian]. 31. Strakh i nenavyst u Feisbuku: yak ukraintsi svariatsya cherez vybory [Fear and Hatred in Facebook: the way Ukrainians argue over elections]. (2 April 2019). BBC. Retrieved from https://www. 
bbc.com/ukrainian/features-47784858 [in Ukrainian]. 32. Tokarev, S. A. (Eds.). (2000). Mify narodov mira [Myths of Peoples of the World]. (Vol. 1). Moscow: Bolshaya Rossiyskaya Enciclopedia [in Russian]. 33. Vovchuk, Kh. (2019a). Svitovi ZMI pro vybory prezydenta Ukrayiny: shansy holovnykh kandydativ i maybutni vidnosyny z RF. Tyzhden - Week. Retrieved from https://tyzhden.ua/World/226279 [in Ukrainian]. 34. Vovchuk, Kh. (2019в). Svit pro rezul'taty pershoho turu vyboriv prezydenta Ukrayiny: nove politychne oblychchya ta stiykyy lider. Tyzhden. Retrieved from https://tyzhden.ua/World/228653 [in Ukrainian]. 35. Yatsimirs'ka, M. \& Dragan, N. (2007). Mediatekst yak produkt zhurnalists'koï tvorchosti (psikholingvistichniy analiz lohichnoho spryynyattya ta emotsiy) [Media text as a product of journalist's creative thought (psycholinguistic analysis of personal perception and emotions)], 30, Lviv: Visnyk Lviv. University, 267-276 [in Ukrainian]. 36. Younge, G. (2019). Brexit is not the cause of Britain's political breakdown a symptom. The Guardian. Retrieved from https://www.theguardian.com/commentisfree/2019/mar/21/brexit-political-crisis-britain [in English].

Крапівник Ганна Олександрівна - доктор філософських наук, кандидат філологічних наук, доцент кафедри англійської філології, Харківський національний педагогічний університет імені Г. С. Сковороди; вул. Валентинівська, 2, м. Харків, 61168, Україна.

Tel.: +38-050-400-5703

E-mail: krap302@gmail.com

ORCID: https://orcid.org/0000-0003-1641-987X

Krapivnyk Hanna - Doctor of Philosophy, PhD in Philology, Associate Professor, Department of English Philology, H. S. Skovoroda Kharkiv National Pedagogical University; Valentynivska Str. 2, Kharkiv, 61168, Ukraine.

Надійшла до редакції 17 лютого 2020 року 